\title{
Increased Indexes of Thrombin Activation in Advanced Stages of Hypertension
}

\author{
Aldo Trifiletti Rina Scamardi Maria Antonia Pizzoleo \\ Gianluca Sottilotta Natale Barbera Nicola Frisina \\ Department of Internal Medicine, University of Messina, Italy
}

\section{Key Words}

Hypertension - Coagulation - Blood pressure

\begin{abstract}
Background: The hemostatic system plays an important role in thrombotic lesions, which can complicate the clinical course of hypertensive patients. The aim of this study was to verify a possible activation of the blood clotting processes, the evaluation of two markers of thrombin activation in 62 hypertensive patients, with and without vascular complications, compared with a control group. Methods and Results: In 22 patients with newly diagnosed uncomplicated essential hypertension, in 40 hypertensive patients with clinically evident vascular complications (20 patients with controlled blood pressure and 20 with uncontrolled and high blood pressure) and in 20 normotensive sex- and age-matched subjects, two indexes of thrombin generation and action, namely prothrombin fragment $1+2(F 1+2)$ and fibrinopeptide
\end{abstract}

\begin{tabular}{ll}
\hline KARGER & ( ) 2001 S. Karger AG, Basel \\
Fax + 4161306 1234-0147/01/0311-0049\$17.50/0 \\
$\begin{array}{l}\text { E-Mail karger@karger.ch } \\
\text { www.karger.com }\end{array}$ & $\begin{array}{l}\text { Accessible online at: } \\
\text { www.karger.com/journals/hae }\end{array}$
\end{tabular}

A (FPA) were evaluated. The observed values show an increase of the $\mathrm{F} 1+2$ levels in patients with overt vascular complications; those with higher blood pressure, moreover, showed FPA levels higher than those with controlled blood pressure. Conclusions: These results seem to indicate that plasma $\mathrm{F} 1+2$ levels are significantly elevated, as a marker of a thrombosis-prone status, in patients with organic damage. Successively, with progress of hypertension and increasing blood pressure, the evidence of elevated FPA levels seems to indicate a clear prethrombotic situation which could turn into a thrombotic state.

Copyright $\odot 2001$ S. Karger AG, Basel

\section{Introduction}

Cardiovascular diseases are the major cause of morbidity and mortality in hypertensive patients. Cardiovascular events are common in populations where atherosclerosis be-
Aldo Trifiletti, MD

Via Monsignor D'Arrigo, n.23

I-98121 Messina (Italy)

Tel. +390902936528, Fax +390902935162

E-Mail atrifiletti@tin.it 
comes more prevalent with duration and degree of hypertension. The hemostatic system plays an important role in the progression of these thrombotic lesions [1-3]. The atherogenic and coagulant risk factors (perivascular and intravascular lesions, aggregation of red blood cells) are significantly higher in people suffering from stable arterial hypertension with a history of minor brain stroke. Several studies in hypertensive subjects [4-10] have shown that platelet reactivity was increased with advancing age $[11,12]$, and von Willebrand factor, $\alpha_{2}$-antiplasmin, D-dimer, tissuetype plasminogen activator and plasminogen activator inhibitor were found to be significantly higher compared with healthy subjects $[4,13]$. Prothrombin fragment $1+2(\mathrm{~F} 1+2)$ and fibrinopeptide A (FPA) were introduced as sensitive markers of thrombin generation and action [14-17]; F1 +2 is the peptide originating from the factor Xa-mediated activation of prothrombin and FPA is the aminoterminal peptide that is cleaved from A- $\alpha$ chain of fibrinogen by the action of thrombin; their elevation reveals an existing prethrombotic or thrombotic stage $[18,19]$. Thrombin generation is most important both in the chronic progression of atherosclerotic disease and in the conversion to acute events. Concordantly, increased levels of markers of thrombin generation and activity are observed during the acute phase [20-22]. In populations where atherosclerosis and cardiovascular events are common, raised blood pressure (BP) is one of the most important established risk factors for stroke and coronary heart disease $[23,24]$. The aim of this study was to determine whether or not these two sensitive markers of accelerated coagulation are abnormal in different stages of arterial hypertension with and without vascular complications.

\section{Material and Methods}

\section{Patients and Controls}

This investigation was carried out in 62 conscutive patients ( 41 men and 21 women between 28 and 69 years of age) with essential hypertension admitted to the Division of Internal Medicine or referred for surgery to the Department of Internal Medicine, University Polyclinic of Messina, Italy. Patients taking oral anticoagulants, with valvular heart disease, with severe heart failure or with any other serious pathology were excluded. Moreover, patients with symptoms of peripheral vascular disease or ischemic heart disease were excluded from this study. All patients were submitted to an echocardiographic study. The main clinical characteristics of the patients and controls are reported in table 1 . The patients were subdivided in two groups. Group 1 consisted of 22 patients with newly diagnosed untreated essential hypertension without objective organic change according to international guidelines [25]: mean systolic BP (SBP) $169.8 \pm 13.2$ $\mathrm{mm} \mathrm{Hg}$, range 160-187, mean diastolic BP (DBP) 92.6 $\pm 6.3 \mathrm{~mm} \mathrm{Hg}$, range $90-118$. Group 2 consisted of 40 patients divided into two subgroups each of 20 patients: subgroup $2 \mathrm{~A}$ whose patients were effectively treated with antihypertensive drugs with $\mathrm{BP}$ at admission of $<160 / 90$ (mean SBP $135.4 \pm 15.3 \mathrm{~mm} \mathrm{Hg}$, range $120-148$ and DBP $83.1 \pm 11 \mathrm{~mm} \mathrm{Hg}$, range 75 88), with hypertensive organic damage (left ventricular hypertrophy, retinopathy, elevated plasma creatinine), and subgroup 2B whose patients were ineffectively treated or untreated with antihypertensive drugs with a BP at entry of $>169 / 90$ (mean SBP $178.8 \pm 13.5 \mathrm{~mm}$ $\mathrm{Hg}$, range $165-228$ and DBP $97.3 \pm 10.2 \mathrm{~mm} \mathrm{Hg}$, range of 90-124). The group 1 and $2 \mathrm{~B}$ patients were not taking antiplatelet drugs. $6 / 20$ patients in group $2 \mathrm{~A}$, who had taken antiplatelet drugs, underwent a 14day washout of these drugs. We also studied 20 healthy sex- and age-matched subjects (13 men and 7 women between 26 and 67 years of age, mean SBP $122.5 \pm 5.2$ $\mathrm{mm} \mathrm{Hg}$, range 98-130, mean DBP $76.5 \pm 6.3 \mathrm{~mm} \mathrm{Hg}$, range $70-82 \mathrm{~mm} \mathrm{Hg}$ ).

\section{Blood Sampling and Assay Methods}

Blood samples were obtained by antecubital venipuncture; blood was drawn between 8 a.m. and 11 a.m. after an overnight fast and $10 \mathrm{~min}$ rest. The first 4$5 \mathrm{ml}$ were not used. Blood was collected into refrigerated vascutainers containing an anticoagulant mixture provided by Boehringer-Mannheim, immediately placed on ice, centrifuged, within a few minutes, at $2,000 \mathrm{~g}$ for $20 \mathrm{~min}$ at $4^{\circ} \mathrm{C}$ and frozen at $-80^{\circ} \mathrm{C}$ for about 3 months until assayed. F1 +2 and FPA were 
Table 1. Clinical characteristics of subjects

\begin{tabular}{lllll}
\hline Parameters & Controls & Group 1 & Group 2A & Group 2B \\
\hline Patients & 20 & 22 & 20 & 20 \\
Age, years & $26-67$ & $28-65$ & $42-69$ & $49-68$ \\
& $(55.0 \pm 10.69)$ & $(53.8 \pm 10.10)$ & $(54.7 \pm 7.18)$ & $(56.4 \pm 5.09)$ \\
Gender (m/f) & $13 / 7$ & $14 / 8$ & $13 / 7$ & $14 / 6$ \\
Body mass index, kg/m ${ }^{2}$ & $24.0 \pm 0.4$ & $23.7 \pm 0.4$ & $24.4 \pm 0.5$ & $24.1 \pm 0.3$ \\
Mean SBP, mm Hg & $122.5 \pm 5.2$ & $169.8 \pm 13.2$ & $135.4 \pm 15.3$ & $178.8 \pm 13.5$ \\
Mean DBP, mm Hg & $76.5 \pm 6.3$ & $92.6 \pm 6.3$ & $83.1 \pm 11.0$ & $97.3 \pm 10.2$ \\
Antihypertensive drugs & 0 & 0 & 20 & 13 \\
Left ventricular hypertrophy & 0 & 0 & 18 & 19 \\
Retinopathy & 0 & 0 & 20 & 20 \\
Elevated creatinine & 0 & 0 & 3 & 5 \\
Antihypertensive medication & 0 & 0 & 20 & 13 \\
ACE inhibitors & 0 & 0 & 13 & 8 \\
$\beta-B l o c k e r s$ & 0 & 0 & 7 & 3 \\
Diuretics & 0 & 0 & 4 & 2 \\
Ca ${ }^{2+}$ channel blockers & 0 & 0 & & 1 \\
\hline
\end{tabular}

measured by ELISA kits providedby BoehringerMannheim (Diagnostica Stago). Two determinations were done (plasma F1 + 2 and FPA levels) for each subject.

\section{Statistical Analysis}

All data are expressed as mean \pm SD. The MannWhitney U test was used for the statistical analysis of $\mathrm{F} 1+2$ and FPA levels in patient groups and controls, since data were not normally distributed. $\mathrm{p}<0.05$ was considered significant.

\section{Results}

The plasma F1 + 2 and FPA levels are reported in figures 1 and 2 . The observed values in group 1 patients show no significant differences compared to the controls for F1+ 2 and FPA $(0.19 \pm 0.07$ vs. $0.19 \pm 0.08$ $\mathrm{nmol} / \mathrm{l}$ and $1.7 \pm 0.6$ vs. $1.6 \pm 0.4 \mathrm{mmol} / \mathrm{l}$, respectively). A significant increase of $\mathrm{F} 1+2$ levels is evident in both subgroups $2 \mathrm{~A}$ and $2 \mathrm{~B}$ compared to the controls and to the group 1 patients $(0.47 \pm 0.09$ and $0.45 \pm 0.08$ vs.
$0.19 \pm 0.08$ and $0.19 \pm 0.07 \mathrm{nmol} / \mathrm{l}$, respectively).

Moreover, subgroup 2B patients showed significantly higher FPA levels than subgroup $2 \mathrm{~A}$ patients $(4.9 \pm 0.7$ vs. $1.8 \pm 0.7 \mathrm{mmol} / \mathrm{l})$, group 1 patients and controls.

\section{Discussion}

To establish the possible activation of the hemostatic system in the development of hypertensive complications we measured levels of F1 + 2 and FPA in the plasma of the studied patients. We found that in group 1 patients, with uncomplicated essential hypertension, the mechanisms of thrombin generation and activity are not activated. On the other hand, the amounts of generated thrombin, correlated to an increase of F1 +2 levels, in group 2 and group 3 patients, seem to suggest an involvement of the blood coagulation in these patients, theoretically ascribable too to 
Fig. 1. Plasma $\mathrm{F} 1+2$ levels in patient groups and controls. The Mann-Whitney U test was used to test for differences between the patient groups (group 1: uncomplicated hypertensive patients, group 2A: complicated controlled hypertensive patients, group 2B: complicated uncontrolled hypertensive patients) and controls. $*$ p $<0.001$ vs. group 1 and controls.

Fig. 2. Plasma FPA levels in patient groups and controls. MannWhitney U test was used to test for differences between the patient groups (group 1: uncomplicated hypertensive patients, group 2A: complicated controlled hypertensive patients, group 2B: complicated uncontrolled hypertensive patients) and controls. $*$ p $<0.001$ vs. group $2 \mathrm{~A}$, group 1 and controls.
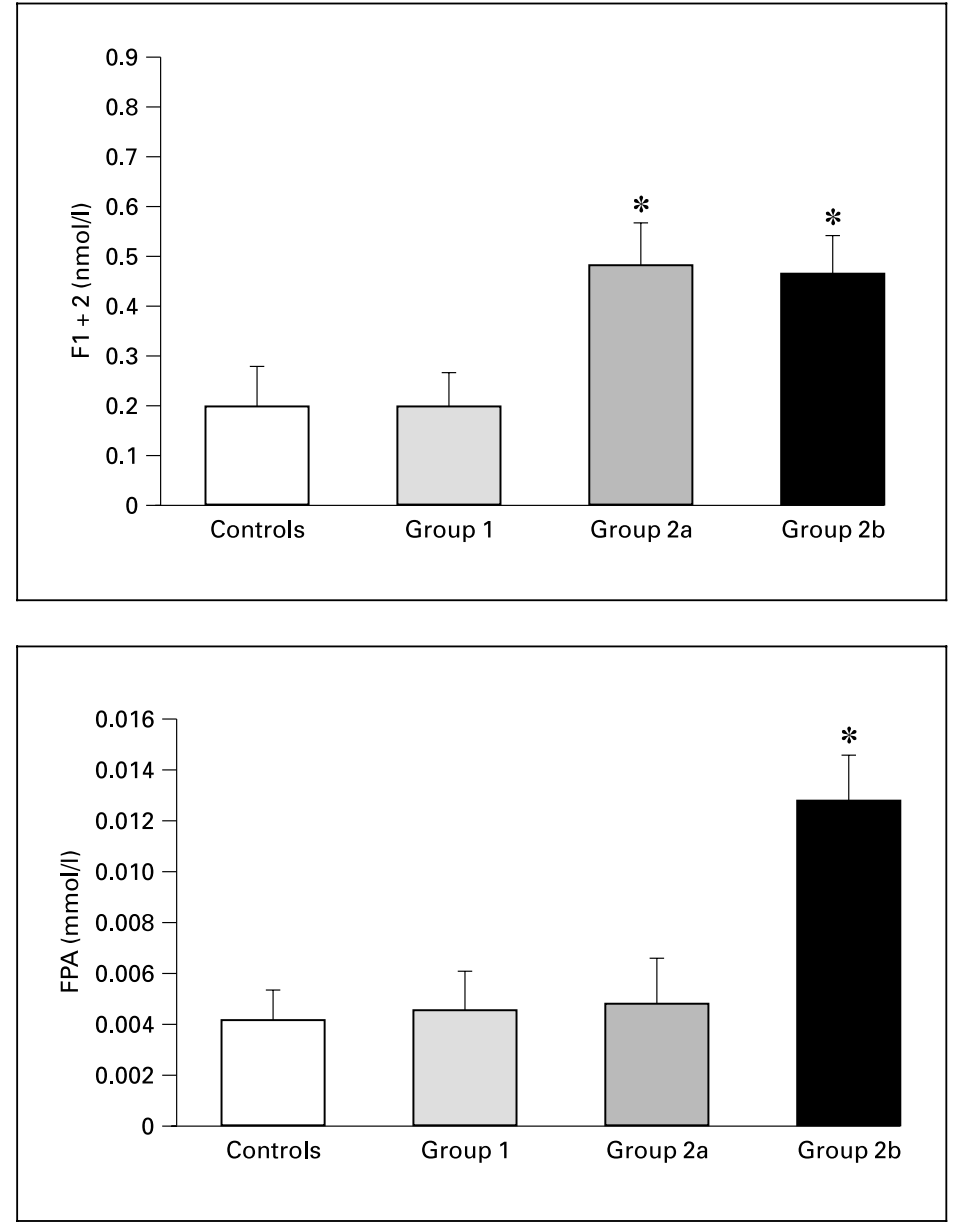

an unfavorable impact of the antihypertensive therapy on the blood clotting system. But scarce and controversial data with respect to such an interaction exist as regards diuretics, $\beta$-blockers and calcium antagonists [26]. Our experience with the hemostatic effects of ACE inhibitors showed that the ACE inhibitor cilazapril does not increase the tendency of blood to clot [27]. Several studies have shown that diuretics and calcium antagonists did not produce any unwanted side effects on platelet function or fibrinolysis $[28,29]$. The increase of $\mathrm{F} 1+2$ in our patients confirms the results of other clinical observations that showed an activated coagulation system in hypertensive patients [30]. We also found significant differences between patients with controlled BP and patients with raised $\mathrm{BP}$, for FPA, which is significantly higher in patients with uncontrolled BP; this difference is not ascribable to an unfavorable impact of the antihypertensive therapy because the group $2 \mathrm{~A}$ and $2 \mathrm{~B}$ patients were treated with similar drugs. Our observation suggests an association between enhanced fibrin turnover and the extent of underlying atherosclerotic disease in these pa- 
tients. F1 +2 and FPA are direct indicators of thrombin generation and action, and well reflect the amounts of generated thrombin and fibrin. High levels of these parameters suggest that the coagulation pathways are activated in these patients. Because thrombin plays a critical role in the amplification of the coagulation cascade by activating factor $\mathrm{V}$ [31] and factor VIII [32-34], persistent thrombin generation may partially contribute to the persistent thrombotic risk of progressing hypertension, especially if the BP is elevated.
We conclude that thrombin generation and activity markers are dangerously increased in patients with hypertensive organic changes when the BP is uncontrolled. These results support the concept of a hypercoagulable state in advanced stages of arterial hypertension. To improve the prognosis the BP should be controlled because a sustained hypertension could play a role in the enlargement of a prethrombotic state.

\section{References}

1 Baumgartner HR, Sakariassen KS: Factors controlling thrombus formation on arterial lesions. Ann NY Acad Sci 1985;454:162-177.

2 Schwartz CJ, Valente AJ, Kelley JL, Sprague EA, Edwards EH: Thrombosis and the development of atherosclerosis: Rokitansky revisited. Semin Thromb Hemost 1988;14/2: 189-195.

3 Davies MJ, Thomas A: Thrombosis and acute coronary-artery lesions in sudden cardiac ischemic death. N Engl J Med 1984;310:1137-1140.

4 Trifiletti A, Barbera N, Pizzoleo MA, Lasco A, Lucifora S, Leone G, Soraci S, Pedulla M, Frisina N: Haemostatic variables in arterial hypertension. Haemostasis 1995;25/5: 237-240.

5 Vaziri ND, Smith DH, Winer RL, Weber MA, Gonzales EC, Neutel JM: Coagulation and inhibitory and fibrinolysis proteins in essential hypertension. J Am Soc Nephrol 1993; 4/2:222-228.

6 van Wersch JW, Rompelberg-Lahaye J, Lustermans FA: Plasma concentration of coagulation and fibrinolysis factors and platelet function in hypertension. Eur J Clin Chem Clin Biochem 1991;29:375-379.

7 Lemne C, Vesterqvist O, Egberg N, Green K, Jogestrand T, de Faire U: Platelet activation and prostacyclin release in essential hypertension. Prostaglandins 1992;44/3:219-235.
8 Urano T, Kojima Y, Takahashi M, Serizawa K, Sakakibara K, Takada Y, Takada A: Impaired fibrinolysis in hypertension and obesity due to high plasminogen activator-inhibitor-1 level in plasma. Jpn J Physiol 1993;43/2:221-228.

9 Donders SH, Lustermans FA, van Wersch JW: Low order correlations of lipoprotein(a) with other blood lipids and with coagulation and fibrinolysis parameters in hypertensive and diabetic patients. Blood Coagul Fibrinolysis 1992;3/3:249256.

10 Donders SH, Lustermans FA, van Wersch JW: Fibrinolysis factors and lipid composition of the blood in treated and untreated hypertensive patients. Blood Coagul Fibrinolysis 1992;3/1:61-67.

11 Sushko OO, Lezhen TI, Platonova TM, Chernishenko TM: A rapid turbidimetric micromethod in the determination of haemostatic and fibrinolytic disorders in arterial hypertensive patients of different ages. Lik Sprava 1993;7:58-60.

12 Amstein R, Fetkovska N, Buhler FR: Age, platelet serotonin kinetics and 5HT2-receptor blockade in essential hypertension. J Hum Hypertens 1990;4:441-444.
13 Gomi T, Ikeda T, Yuhara M, Sakurai J, Nakayama D, Ikegami F: Plasma beta-thromboglobulin to platelet factor 4 ratios as indices of vascular complications in essential hypertension. J Hypertens 1988;6:389-392.

14 Pelzer H, Schwarz A, Stuber W: Determination of human prothrombin activation fragment $1+2$ in plasma with an antibody against a synthetic peptide. Thromb Haemost 1991;65/ 2:153-159.

15 Nossel HL, Younger LR, Wilner GD, Procupez T, Canfield RE, Butler VP Jr: Radioimmunoassay of human fibrinopeptide A. Proc Natl Acad Sci USA 1971;68:2350-2353.

16 Nossel HL, Yudelman I, Canfield RE, Butler VP Jr, Spanondis K, Wilner GD, Qureshi GD: Measurement of fibrinopeptide A in human blood. J Clin Invest 1974;54/1:4353.

17 Nossel HL, Ti M, Kaplan KL, Spanondis $\mathrm{K}$, Soland T, Butler VP Jr: The generation of fibrinopeptide A in clinical blood samples: Evidence for thrombin activity. J Clin Invest 1976;58:1136-1144.

18 Bauer KA, Rosemberg RD: The pathophysiology of the prethrombotic state in humans: Insight gained from studies using markers of hemostatic system activation. Blood 1987;70:343-350. 
19 Gertler JP, Abbott WM: Prothrombotic and fibrinolytic function of normal and perturbed endothelium. J Surg Res 1992;52/1:89-95.

20 Merlini PA, Bauer KA, Oltrona L, Ardissino D, Cattaneo M, Belli C, Mannucci PM, Rosemberg RD: Persistent activation of coagulation mechanism in unstable angina and myocardial infarction. Circulation 1994;90/1:61-68.

21 Biasucci LM, Liuzzo G, Caligiuri G, Quaranta G, Andreotti F, Sperti G, van de Greef W, Rebuzzi AG, Kluft $\mathrm{C}$, Maseri A: Temporal relation between ischemic episodes and activation of the coagulation system in unstable angina. Circulation 1996;93: 2121-2127.

22 Ardissino D, Merlini PA, Gamba G, Barberis P, Demicheli G, Testa S, Colombi E, Poli A, Fetiveau R, Montemartini C: Thrombin activity and early outcome in unstable angina pectoris. Circulation 1996;93: 1634-1639.

23 McMahonon S, Peto R, Cutler J, Collins R, Sorlie P, Neaton J, Abbott R, Godwin J, Dyer A, Stamler $\mathrm{J}$ : Blood pressure, stroke and coronary heart disease. 1. Prolonged differences in blood pressure: Prospective observational studies corrected for the regression dilution bias. Lancet 1990;335:765-774.
24 Koczko J, Wojtukiewicz MZ, Gakar M, Tarasow E, Jaromin J, Bielawiec M: Prothrombin activation fragment $1+2$ and thrombin-antithrombin-III complexes in plasma of patients with essential hypertension. Pol J Pharmacol 1996;48/2: 233-235.

251993 guidelines for the management of mild hypertension: Memorandum from a World Health Organization/International Society of Hypertension meeting. Guidelines SubCommittee. J Hypertens 1993;11: 905-918.

26 Lottermoser K, Weisser B, Hertfelder HJ, Wostmann B, Vetter H, Dusing R: Antihypertensive drug treatment and fibrinolytic function. Am J Hypertens 1998;11:378-384.

27 Trifiletti A, Barbera N, Scamardi R, Bagnato L, Nevoso A, Lasco A, Pedullà $M$, Frisina N: Effect of medium-term antihypertensive therapy on haemostatic parameters in patients with essential hypertension. Haemostasis 1997;27:35-38.
28 Gleerup G, Petersen JR, Mehlsen J, Winther K: Effects of spirapril and hydrochlorothiazide on platelet function and euglobin clot lysis time in patients with mild hypertension. Angiology 1996;47:951-955.

29 Fujinishi A, Takahara K, Ohba C, Nakashima Y: Calcium, platelet aggregation, and coagulation/fibrinolysis in patients with coronary artery disease. Angiology 1997;48:515521.

30 Donders SH, Lustermans FA, van Wersch JW: Prothrombin fragment 1.2 in both treated and untreated hypertensive patients. Neth $\mathrm{J}$ Med 1993;43/3-4:174-178.

31 Nesheim ME, Mann KG: Thrombin-catalyzed activation of single chain bovine factor V. J Biol Chem 1979;254:1326-1334.

32 Hoyer LW, Trabold NC: The effect of thrombin on human factor VIII Cleavage of the factor VIII procoagulant protein during activation. $\mathrm{J}$ Lab Clin Med 1981;97/1:50-64.

33 Pieters J, Lindhout T, Hemker HC: In situ-generated thrombin is the only enzyme that effectively activates factor VIII and factor $\mathrm{V}$ in thromboplastin-activated plasma. Blood 1989;74:1021-1024. 